ISSN 2442-3041

Math Didactic: Jurnal Pendidikan Matematika

Vol. 1, No.1, Januari - April 2015

(C) STKIP PGRI Banjarmasin

\title{
SCAFFOLDING DALAM PEMBELAJARAN MATEMATIKA ${ }^{5}$
}

\author{
Zahra Chairani \\ STKIP PGRI Banjarmasin. \\ E-mail: zahralmp@yahoo.com
}

\begin{abstract}
Abstrak: Dalam belajar matematika, siswa menggunakan strategi kognitif untuk dapat menentukan bagaimana ia belajar, bagaimana ia memanggil kembali informasi, menggunakan apa yang dipelajari, dan bagaimana ia berpikir untuk mendapatkan strategi penyelesaian masalah yang tepat, sehingga ia dapat mencapai tujuan kognitif yaitu menyelesaikan masalah. Dalam menyelesaikan masalah, prosedur penyelesaian masalah matematika merupakan proses kognitif berdasarkan halhal yang sudah diketahuinya. Tidak jarang dalam pelaksanaan pembelajaran, terutama pada saat siswa memecahkan masalah matematika, siswa menemui kesulitan. Untuk mengatasi kesulitan ini diperlukan peranan guru atau orang lain yang dapat menjadi fasilitator dan motivator dalam meminimalkan kesulitan dan mengarahkan proses kognitif untuk membantu siswa menyelesaikan masalahnya. Salah satu alternatif penerapan scaffolding memuat komponen-komponen eksplaining, reviewing, restructuring, dan developing conceptual thinking.
\end{abstract}

Kata kunci: scafolding, memecahkan masalah, proses kognitif.

Matematika sekolah, bertujuan agar dapat mengembangkan kemampuan berpikir siswa, membekali siswa dalam berpikir logis, kritis, analitis, sistematis, dan kreatif, serta kemampuan bekerjasama. Kemampuan tersebut dapat dikembangkan melalui pendekatan pemecahan masalah matematika yaitu kemampuan dalam memahami masalah, merancang model matematika, menyelesaikan model dan menafsirkan solusi yang diperoleh (Depdiknas: 2006).

Polya (1980) menyatakan bahwa, menyelesaikan masalah adalah suatu kemampuan khusus dari kecerdasan. Banyak rintangan untuk dapat mengembangkan kemampuan ini. Kewajiban guru matematika adalah menggunakan kemampuan yang dimiliki siswa dan mengembangkan kemampuan khusus siswa tersebut untuk menyelesaikan masalah. Dalam menyelesaikan masalah, prosedur penyelesaian masalah matematika merupakan proses kognitif berdasarkan halhal yang sudah diketahuinya. Dalam hal ini siswa menggunakan strategi kognitif untuk dapat menentukan bagaimana ia belajar, bagaimana ia memanggil kembali informasi, menggunakan apa yang dipelajari, dan bagaimana ia berpikir.untuk mendapatkan strategi penyelesaian masalah yang tepat, sehingga ia dapat mencapai tujuan kognitif

\footnotetext{
${ }^{5}$ Disampaikan pada Seminar Nasional Pendidikan Matematika STKIP PGRI Banjarmasin, 28 Januari 2015
} 
yaitu menyelesaikan masalah.

Tidak jarang dalam pelaksanaan pembelajaran, terutama pada saat siswa memecahkan masalah matematika siswa seringkali mengalami kesulitan dalam berbagai hal antara lain (1) kesulitan dalam mengutarakan apa yang dipikirkannya, baik dengan cara lisan maupun tertulis, (2) kesulitan dalam mengkaitkan informasi baru dengan pengetahuan yang dimilikinya,(3) kesulitan dalam melakukan algorithme, (4) kesulitan dalam melakukan manipulasi aljabar. Solso (2008) mengemukakan bahwa kesulitan tersebut dapat disebabkan pada beberapa hal, antara lain (1) minimnya pengetahuan siswa (2) kurangnya kemampuan siswa dalam menyimpan informasi yang diterimanya, (3) rendahnya kecerdasan yang dimiliki siswa, (4) kurangnya kemampuan mengkontrol dan memonitor proses berpikirnya. Untuk mengatasi kesulitan ini diperlukan peranan guru atau orang lain yang dapat menjadi fasilitator dan motivator dalam meminimalis kesulitan dan mengarahkan pemikirannya untuk mendapatkan jalan yang dapat membantu siswa menyelesaikan masalahnya.

Dalam penelitian disertasi tentang metakognisi, Chairani. Z (2014) mendapatkan kenyataan bahwa siswa dengan kemampuan rendah memerlukan waktu yang lebih lama dibandingkan siswa yang berkemampuan menengah dan tinggi dalam memecahkan masalah tanpa adanya intervensi atau bantuan. Kesulitan ini sebenarnya dapat diatasi apabila diberikan bantuan untuk mengarahkan siswa sehingga masalahnya dapat selesai dengan lebih cepat. Dalam hal ini penulis tertarik untuk mencari solusi bagaimana membantu siswa yang mengalami kesulitan belajar matematika dengan mengetengahkan peranan scaffolding sebagai solusi dengan pertimbangan bahwa peranan bantuan di saat diperlukan siswa adalah sesuatu yang sangat berarti dan merupakan hal penting.

\section{Pengertian Scaffolding}

Scaffolding yang dimaksudkan dalam artikel ini adalah pemberian bantuan secukupnya kepada siswa yang didasarkan pada bentuk kesulitan yang dialami oleh siswa. Scaffolding pertama kali digagas oleh Vygotsky, seorang ahli psikologi dari Rusia, yang selanjutnya dipopulerkan oleh Bruner, seorang ahli pendidikan matematika.

Vygotsky mengutarakan gagasan Zone of Proximal Development (ZPD) dan Scaffolding. Menurut Vygotsky (dalam Supiyani, 2013), setiap anak mempunyai apa yang disebut dengan Zone of Proximal Development (ZPD), yang dikatakan sebagai jarak antara tingkat perkembangan actual dengan tingkat perkembangan potensial yang lebih tinggi. Dalam hal ini Vygotsky berpendapat bahwa ,siswa akan mampu mencapai daerah maksimal bila dibantu secukupnya. Apabila siswa belajar tanpa dibantu, dia akan tetap berada di daerah actual tanpa bisa berkembang ketingkat perkembangan potensial yang lebih tinggi. Selanjutnya yang menjadi masalah adalah bagaimana menyusun strategi scaffolding yang efektif dan efisien sehingga bisa mengembangkan kemampuan actual siswa kearah kemampuan potensial. .

Pada saat siswa berada pada potensi aktual, guru berharap siswa akan dapat mencapai kemampuan potensial secara maksimal. Berbagai kesulitan yang dapat dialami siswa dalam melakukan aktivitas kognitif agar dapat mencapai kemampuan potensial, menurut Ormrod (2008) dipengaruhi oleh: (1) Memori kerja yang menjadi batas atas bagi siswa pada saat memecahkan masalah, (2) Kesulitan siswa dalam mengkodekan suatu masalah yang berpengaruh pada pendekatan yang digunakan untuk memecahkan masalah, (3) Basis pengetahuan yang dimiliki siswa tidak menyeluruh dan tidak terintegrasi dengan baik dan relevan pada topik yang dipikirkan, dan 
(4) Kesulitan dalam kesuksesan memanggil kembali pengetahuan yang relevan

Dalam pembelajaran, scaffolding dapat dikatakan sebagai jembatan yang digunakan untuk menghubungkan apa yang sudah diketahui siswa dengan sesuatu yang baru atau yang akan dikuasai/diketahui siswa. Hal yang utama dalam penerapan scaffolding terletak pada bimbingan guru. Bimbingan guru diberikan secara bertahap setelah siswa diberi permasalahan, sehingga kemampuan aktualnya mencapai kemampuan potensial. Bantuan tersebut dapat berupa petunjuk, dorongan, peringatan, menguraikan masalah ke dalam langkah-langkah pemecahan, atau memberikan contoh.

Tiga ide utama Vygotsky adalah:

1. Intelektual berkembang pada saat individu menghadapi ide-ide baru dan sulit mengaitkan ide-ide tersebut dengan apa yang mereka ketahui.

2. Interaksi dengan orang lain memperkaya perkembangan intelektual.

3. Peran utama guru adalah bertindak sebagai seorang pembantu dan mediator pembelajaran

Vygotsky memunculkan konsep scaffolding, yaitu memberikan sejumlah bantuan kepada seorang siswa selama tahap-tahap awal pembelajaran dan kemudian mengurangi bantuan tersebut dan memberikan kesempatan kepada siswa tersebut untuk mengambil alih tanggung jawab yang semakin besar segera setelah ia dapat melakukannya (Slavin, 2009). Sebagian pakar pendidikan mendefinisikan scaffolding berupa bimbingan yang diberikan oleh seorang guru kepada peserta didik dalam proses pembelajaran dengan persoalanpersoalan terfokus dan interaksi yang bersifat positif.

\section{Scafolding dalam Teori Belajar Kognitif}

Salah satu teori belajar kognitif adalah konstruktivis. Piaget (dalam Suparno, 2001) menyatakan bahwa pengetahuan seseorang adalah bentukan orang itu sendiri. Tanpa keaktifan seseorang dalam mencerna dan membentuknya seseorang tidak akan mempunyai pengetahuan. Secara ekstrim Piaget menyatakan bahwa pengetahuan tidak dapat ditransfer dari otak guru yang tidak mengolah dan membentuknya sendiri. Pendapat Piaget lebih bersifat individual.

Perpaduan antara pendapat Piaget dan Vygotsky mendapatkan garis besar prinsipprinsip konstruktivis sosial dengan pendekatan scaffolding yang diterapkan dalam pembelajaran adalah sebagai berikut:

1. Pengetahuan dibangun oleh peserta didik sendiri.

2. Pengetahuan tidak dapat dipindahkan dari pembelajar ke peserta didik, kecuali hanya dengan keaktifan peserta didik sendiri untuk menalar.

3. Peserta didik aktif mengkontruksi secara terus menerus, sehingga selalu terjadi perubahan konsep ilmiah.

4. Guru sekedar memberi bantuan dan menyediakan saran serta situasi agar proses kontruksi belajar lancar.

5. Menghadapi masalah yang relevan dengan peserta didik.

6. Struktur pembelajaran seputar konsep utama pentingnya sebuah pertanyaan.

7. Mencari dan menilai pendapat peserta didik.

8. Menyesuaikan kurikulum untuk menanggapi anggapan peserta didik.

Scaffolding adalah bantuan (parameter, aturan atau saran) pembelajar memberikan peserta didik dalam situasi belajar. Scaffolding memungkinkan peserta didik untuk mendapat bantuan melalui keterampilan baru atau di luar kemampuannya. Konstruksi scaffolding terjadi pada peserta didik yang tidak dapat mengartikulasikan atau menjelajahi belajar secara mandiri. Scaffolding dipersiapkan oleh guru untuk tidak mengubah sifat atau tingkat kesulitan 
dari tugas, melainkan dengan scaffolding yang disediakan memungkinkan siswa untuk berhasil menyelesaikan tugas.

Menurut Vygotsky, siswa mengembangkan keterampilan berpikir tingkat yang lebih tinggi ketika mendapat bimbingan (scaffolding) dari seorang yang lebih ahli atau melalui teman sejawat yang memiliki kemampuan lebih tinggi Demikian juga Piaget berpendapat bahwa siswa akan mendapat pencerahan ide-ide baru dari seseorang yang memiliki pengetahuan atau memiliki keahlian (Piaget, dalam Suparno, 2001).

Beberapa aspek khusus yang dapat membantu peserta didik dalam presentasi pengetahuan secara internal sebagai penguasaan pengetahuan menurut Lange (2002), dalam Hartuti, (2010) sebagai berikut:

1. Intensionalitas: Kegiatan ini mempunyai tujuan yang jelas terhadap aktivitas pembelajaran berupa bantuan yang selalu didiberikan kepada setiap peserta didik yang membutuhkan.

2. Kesesuaian: Siswa yang tidak bisa menyelesaikan sendiri permasalahan yang dihadapinya, maka siswa diberikan bantuan sesuai dengan kesulitan yang dialaminya, bukan untuk menyelesaikan masalahnya, tetapi siswa diberikan kesempatan untuk menyelesaikan sendiri masalahnya dengan bantuan guru.

3. Struktur: Modeling dan mempertanyakan kegiatan terstruktur di sekitar sebuah model pendekatan yang sesuai dengan tugas dan mengarah pada urutan dalam pemikiran dan bahasa.

4. Kolaborasi: Menciptakan kerjasama dengan siswa dan menghargai karya yang telah dicapai oleh peserta didik. Peran guru adalah kolaborator bukan sebagai evaluator.

5. Internalisasi: Eksternal scaffolding untuk kegiatan ini secara bertahap ditarik sebagai pola yang diinternalisasi oleh peserta didik .

\section{Penerapan Scaffolding dalam Pemecahan Masalah Matematika}

Widdiharto (2008) berpendapat bahwa dalam menemukan dan mengatasi kesulitan belajar siswa dalam matematika terlebih dahulu mendiagnosis kesulitan tersebut. Dengan mengetahui letak kesulitan siswa hal tersebut dijadikan salah satu acuan untuk melakukan perbaikan perencanaan maupun pelaksanaan pembelajaran berikutnya. Penelitian Yusi Hartutik (2010) mengemukakan penerapan scaffolding yang mengacu pada Anghileri (2006), yang memuat komponen-komponen eksplaining, reviewing, restructuring, dan developing conceptual thinking.

Penerapan scaffolding sebagai contoh pada artikel ini adalah pemecahan masalah soal cerita dengan menggunakan sistem persamaan linier dengan dua variable di SMP. Ruang lingkup materi yang berada pada ZPD meliputi; (a) Memahami masalah untuk menentukan yang diketahui dan ditanyakan, (b) Menentukan model matematika strategi untuk menentukan nilai variabel (c) Melakukan algorithme untuk menyelesaikan system persamaan dengan dua variable. (d) Menguji kebenaran nilai variabel yang diperoleh, (e) Menafsirkan nilai variabel dengan tujuan permasalahan.

Scafolding setiap langkah penyelesaian dapat dilakukan sebagai berikut.

1. Untuk memahami masalah dari soal cerita sampai siswa dapat apa y6ang diketahui dan ditanyakan, dapat dilakukan guru dengan mengarahkan siswa agar membaca dengan cermat, hati-hati dan teliti untuk menerima informasi dari soal. Untuk mengarahkan siswa dalam hal ketidak mampuan mencari hubungan antara hal yang diketahui dengan yang ditanyakan 
guru dapat menggunakan strategi explaining, yaitu menjelaskan bahwa dengan membaca soal kembali siswa akan memperoleh kalimat mana dalam soal cerita yang dapat di persepsikan sebagai diketahui dan kalimat mana yang dapat dipersepsikan sebagai yang ditanyakan.

2. Dengan menentukan apa yang diketahui dan ditanyakan, guru dapat menggunakan strategi reviewing dengan mengingatkan cara-cara yang tepat untuk menentukan variabel yang digunakan sehingga diperoleh model matematika, dan explaining bahwa antara soal cerita yang sudah dipahami tersebut terdapat suatu kaitan atau hubungan yang merupakan developing conceptual thinking, yang akhirnya diarahkan untuk mentukan strategi yang digunakan misalnya, dengan eliminasi, substitusi atau campuran keduanya.

3. Pada saat siswa melakukan perhitungan atau algorithme untuk mendapatkan nilai variabel dari strategi yang sudah ditentukan, besar kemungkinan kesulitan yang dilakukan setiap siswa akan berbedabeda. Guru dapat menggunakan explaining untuk mengarahkan cara menyelesaikan jika kesalahan dilakukan lebih dari 50\% siswa, secara individual jika kesulitan hanya dilakukan beberapa individu saja.. Menggunakan developing conceptual thinking dalam hal yang berkaitan dengan konsep-konsep yang digunakan dalam algorithme.

4. Setelah hasil diperoleh, dengan revieuwing dan explaining guru memberikan arahan untuk melakukan restructuring agar hasil yang diperoleh tidak menyimpang dari tujuan permasalahan.

5. Penting untuk menafsirkan nilai variable yang diperoleh dengan apa yang harus dicari dari soal. Dengan developing conceptual thinking, guru mengarahkan siswa untuk mengkait kan perolehannya dengan apa yang ditanyakan.

\section{Kesimpulan}

Berdasarkan uraian di atas dapat disimpulkan bahwa, scaffolding merupakan suatu cara yang dapat digunakan guru untuk meminimalis kesulitan siswa dalam belajar matematika ataupun dalam pemecahan masalah matematika. Belajar dalam konstruktivis adalah bentukan hasil pikiran siswa sendiri, oleh karena itu scaffolding yang diberikan guru bukanlah menyelesaikan masalah siswa tetapi merupakan merupakan bantuan atau arahan dengan mengkaitkan kesulitan siswa dalam ZPD untuk meningkatkan perkembangan kemampuan potensial. Sebagai alternative dalam memberikan scaffolding, artikel ini mengetengahkan suatu contoh pemberian scaffolding dengan menggunakan explaining, reviewing, restructuring, dan developing conceptual thinking.

Disarankan agar sebelum memberikan scaffolding guru melakukan diagnosis kesulitan belajar siswa dan memahami aspek kemampuan berpikir siswa sehingga bantuan yang diberikan tepat dan sesuai untuk digunakan dalam meningkatkan perkembangan kemampuan aktual siswa menjadi kemampuan potensial secara maksimal.

\section{Daftar Pustaka}

Anghileri, J. 2006. Scafolding Practices That Enhance Mathematics Learning. Journal of Mathematics Teacher Education. 9:33-52.

Cahyono Nur Adi. 2010. Vygotsky Perspectif: Proses Scafolding Untuk mencapai Zona Proximal Development Peserta Didik dalam Pembelajaran Matematika. Makalah Disajikan pada Seminar Nasional Matematika dan Pendidikan Matematika 27 Nopember 2010. 
Chairani, Z. 2014. Profil Metakognisi Siswa SMP dalam Pemecahan Masalah Aljabar Berdasarkan Kemampuan Siswa. Disertasi. Pascasarjana S3. Universitas Negeri Surabaya. (UNESA).

Dahar, R.W. 1988. Teori-teori Belajar, Jakarta: Depdikbud. P2LPTK.

Hartutik, Y. dkk. 2010. Proses Scafolding Berdasarkan Diagnosis Kesulitan Siswa dalam Menyelesaikan Masalah Pertidaksamaan Kudrat dengan Menggunakan Mapping Mathematics. Makalah Prosiding Konferensi Nasional Pendidikan Matematika, Malang 27-30 Juni 2013

Julia A., 2006. Scaffolding Practices that Enhance Mathematics Learning. Journal of Mathematics Teacher Education. Volume 9, pp 33-52.

PPPPTK Matematika.2007. Metapora Scaffolding pada Teori Pembelajaran (Matematika).

http//:www.edukasiana.com/. Diakses Jum'at 23 Januari 2015.

Polya, George. 1973. How To Solve It. A New Aspect of Mathematical Method. Princeton, New Jersey: Stanford University. Second Edition. Princeton University Press.

Springer. Ormrod, J.E. 2008. Psikologi Pendidikan. Membantu Siswa tumbuh dan Berkembang (jilid 1). Penerbit Erlangga. Jakarta

Supiani, Anik, dkk. Proses Berpikir Siswa Kelas IX-G SMP Negeri I Wlingi Dalam Memecahkan Masalah Persamaan Garis Lurus dengan Scafolding. Makalah Prosiding Konferensi Nasional Pendidikan Matematika, Malang 27-30 Juni 2013.

Suparno,P. 2001. Teori Perkembangan Kognitif Piaget. Penerbit Kanisius. Yogyakarta.

Valmband. 2008. Teori Perkembangan Kognitif Vygotsky. http://www.valm bandmultiply. com/. Diakses pada Selasa, 10 Agustus 2010.
Widdhiharto, R.2008. Diagnosis Kesulitan Belajar Matematika SMP Alternatif Proses Remidinya. P4TK Yogyakarta. 